\title{
Portal pyaemia following renal transplantation
}

\author{
Abdul R Hakeem, Nasir Nasim, Syed S Raza, Niaz Ahmad
}

Division of Surgery,

Department of HPB and Transplantation, St James's University Hospital NHS Trust, Leeds, UK

\section{Correspondence to}

Abdul R Hakeem,

drhabdulrahman@yahoo.com

Accepted 6 April 2014

\section{CrossMark}

To cite: Hakeem AR, Nasim N, Raza SS, et al. BMJ Case Rep Published online: [please include Day Month Year] doi:10.1136/ bcr-2014-204026

\section{DESCRIPTION}

A 65-year-old man underwent deceased donor renal transplant for end-stage renal disease secondary to sepsis from previous spinal abscess. His comorbidities included Child A alcoholic liver cirrhosis, type-2 diabetes mellitus and previous pulmonary tuberculosis. There was delayed graft function needing dialysis. $\mathrm{He}$ had unknown source of sepsis on the eighth postoperative day with deranged liver function tests, needing broad-spectrum antibiotics. Ultrasound of the abdomen and renal transplant confirmed cirrhotic liver, but was otherwise within normal limits. On the 10th postoperative day, he reported with vague abdominal pain with bright red per-rectal bleeding. A contrast-enhanced CT of the abdomen and pelvis showed widespread mesenteric gas in the vascular arcades of the small bowel mesentery with diffuse small bowel dilation (figure 1). There was air-fluid level within the superior mesenteric vein and its tributaries, splenic and portal veins (figure 2). He was diagnosed as ischaemic bowel with portal pyaemia. Laparotomy and resection of more than $100 \mathrm{~cm}$ of ischaemic small bowel was carried out. The patient died 4 days postlaparotomy due to multiorgan failure.

Portal pyaemia is a potentially life-threatening condition characterised by a combination of infection and thrombosis within the portal vein. ${ }^{1}$ There are two possible theories for air entering the venous system: mechanical theory due to ischaemic bowel damage and bacterial theory due to gasforming organisms. ${ }^{2}$ The clinical presentation largely depends on the underlying pathology and most patients will be profoundly septic. However, some patients can be asymptomatic until later stage, as in our patient, where the presentation was likely masked by post-transplant immunosuppression. ${ }^{3}$

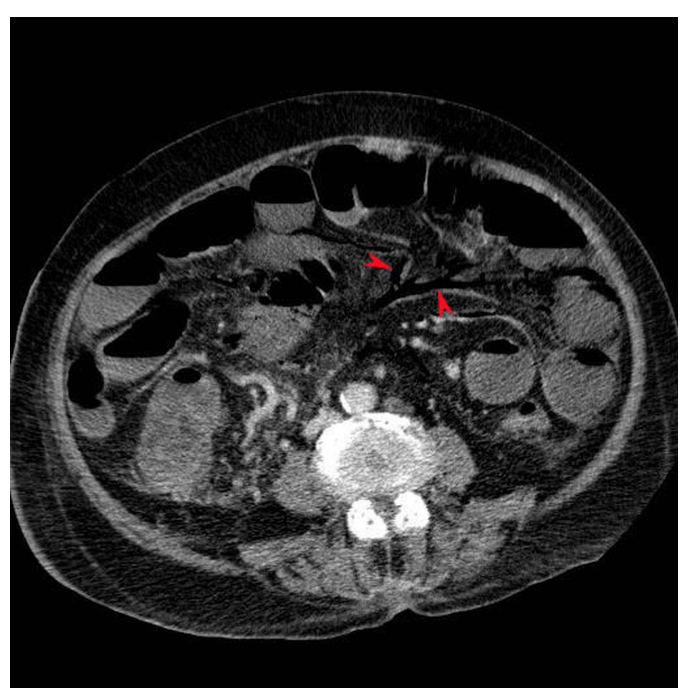

Figure 1 Image showing air within the superior mesenteric vein and its tributaries.

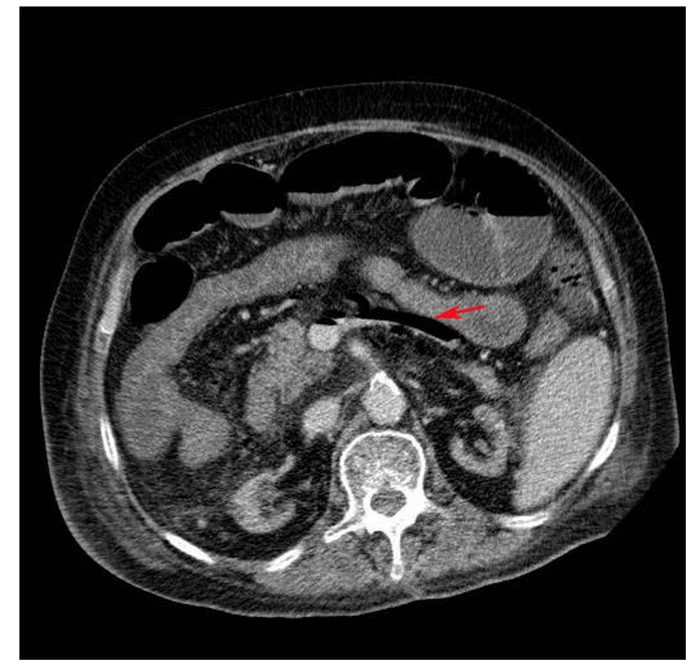

Figure 2 Image showing air within the splenic vein.

\section{Learning points}

- Intestinal pneumatosis (presence of gas in the intestinal wall) and portal pyaemia (presence of gas within portal circulation) are infrequent conditions that have shown to be associated with extensive bowel necrosis and fatal outcome.

- Successful management of portal pyaemia involves early identification of the condition, intensive resuscitation, broad-spectrum antibiotics and laparotomy for possible ischaemic bowel.

- There are a number of algorithms available in the literature for the diagnosis and management of this condition, however in most cases the prognosis remains extremely poor. ${ }^{3}$

Contributors ARH and NN wrote the initial draft and formatted the images. SSR and NA revised the final draft and edited the manuscript.

Competing interests None.

Patient consent Obtained.

Provenance and peer review Not commissioned; externally peer reviewed.

\section{REFERENCES}

1 Sebastià C, Quiroga S, Espin E, et al. Portomesenteric vein gas: pathologic mechanisms, CT findings, and prognosis. Radiographics 2000;20:1213-24.; discussion 1224-6.

2 Kesarwani V, Ghelani DR, Reece G. Hepatic portal venous gas: a case report and review of literature. Indian I Crit Care Med 2009;13:99-102.

3 Mohammed AH, Mohammed AH, Khot UP, et al. Portal venous gas - case report and review of the literature. Anaesthesia 2007:62:400-4. 
Copyright 2014 BMJ Publishing Group. All rights reserved. For permission to reuse any of this content visit http://group.bmj.com/group/rights-licensing/permissions.

BMJ Case Report Fellows may re-use this article for personal use and teaching without any further permission.

Become a Fellow of BMJ Case Reports today and you can:

- Submit as many cases as you like

- Enjoy fast sympathetic peer review and rapid publication of accepted articles

- Access all the published articles

- Re-use any of the published material for personal use and teaching without further permission

For information on Institutional Fellowships contact consortiasales@bmjgroup.com

Visit casereports.bmj.com for more articles like this and to become a Fellow 